\title{
TEMUAN OTOPSI PADA KEMATIAN MENDADAK AKIBAT PENYAKIT JANTUNG DI BLU RSU PROF. DR. R.D. KANDOU MANADO PERIODE 2007-2011
}

\author{
${ }^{1}$ Jessyca Destiana Rorora \\ ${ }^{2}$ Djemi Tomuka \\ ${ }^{2}$ James Siwu \\ ${ }^{1}$ Kandidat Skripsi Fakultas Kedokteran Unuversitas Sam Ratulangi Manado \\ ${ }^{2}$ Bagian Ilmu Kedokteran Forensik dan Medikolegal Fakultas Kedokteran \\ Universitas Sam Ratulangi Manado \\ Email: jzzyjzzy@ymail.com
}

\begin{abstract}
Every sudden death has to be treated as an uncommon death before it can be proved scientifically that there is no evidence supporting the case. Heart disease is the most common cause of sudden death. This research is aimed to know how autopsy findings of sudden death cause by heart disease in BLU RSU Prof Dr. R.D. Kandou Manado period 2007-2011. Research design is descriptive observational using secondary data. Between 2007 to 2011 period, there is a total of 873 cases that come in to forensic department of BLU RSU Prof. Dr. R.D. Kandou. From all those cases, of which there are 62 cases discovery of bodies then proved by autopsy with the result that 10 of them is a sudden death caused by heart disease, with the most caused by coronary artery disease (50\%) followed by miocard lesion disease (40\%). Further research needs to be done to determine which heart disease the most is found to be the death cause in forensic department of BLU RSU Prof. Dr. R.D. Kandou more clearly.
\end{abstract}

Keywords: autopsy, heart disease, sudden death.

\begin{abstract}
Abstrak: Setiap kematian mendadak harus diperlakukan sebagai kematian yang tidak wajar, sebelum dapat dibuktikan secara ilmiah bahwa tidak ada bukti-bukti yang mendukungnya. Penyakit jantung merupakan penyakit yang paling sering menyebabkan kematian. Penelitian ini bertujuan untuk mengetahui bagaimana temuan otopsi pada kasus kematian mendadak akibat penyakit jantung di BLU RSU Prof. Dr. R.D. Kandou Manado periode 2007-2011. Desain penelitian ini adalah deskriptif observasional menggunakan data sekunder yang telah ada. Selama periode 2007 sampai dengan 2011, total jumlah kasus forensik yang masuk di bagian ilmu kedokteran Forensik BLU RSU Prof. dr. R.D. Kandou Manado berjumlah total 873 kasus. Dari sejumlah kasus tersebut, diantaranya terdapat 62 kasus penemuan mayat yang kemudian dibuktikan dengan otopsi sehingga didapatkan 10 mayat yang telah terbukti merupakan kasus kematian mendadak akibat penyakit jantung dengan penyebab terbanyak adalah penyakit arteri koroner (50\%) diikuti dengan penyakit lesi miokard (40\%). Perlu dilakukan penelitian lebih lanjut agar dapat lebih menggambarkan penyakit jantung penyebab kematian terbanyak di bagian Ilmu Forensik BLU RSU Prof. Dr. R.D. Kandou Manado dengan jelas. Kata kunci: kematian mendadak, penyakit jantung, otopsi.
\end{abstract}

Kematian sering terjadi tanpa diduga, terjadi tiba-tiba dan dengan cara yang terkadang tampak tidak wajar. Setiap kematian mendadak harus diperlakukan sebagai kematian yang tidak wajar, sebelum dapat dibuktikan secara ilmiah bahwa tidak ada bukti-bukti yang mendukungnya. Pada kasus kematian yang terjadi seketika atau tak terduga, khususnya bila ada tanda-tanda penyakit sebelumya dan kemungkinan sakit sangat kecil, untuk menentukan penyebabnya perlu dilakukan otopsi pada jenazah. ${ }^{1}$ Hal ini diperlukan untuk 
menentukan apakah termasuk kematian yang wajar atau tidak.

Terminologi kematian mendadak sendiri dibatasi pada suatu kematian alamiah yang terjadi tanpa diduga dan terjadi secara mendadak, mensinonimkan kematian mendadak dengan terminologi Sudden Natural Unexpected Death. ${ }^{2}$ Kematian alamiah disini berarti kematian hanya disebabkan oleh penyakit dan bukan akibat trauma atau racun.

Kematian mendadak dapat disebabkan oleh beberapa hal, salah satunya penyakit jantung. Penyakit jantung merupakan salah satu penyakit yang paling sering menyebabkan kematian. Di dunia, penyakit jantung masih menempati urutan teratas sebagai penyakit yang menyebabkan kematian diikuti dengan penyakit infeksi dan kanker. ${ }^{3}$ Penyebab penyakit jantung itu sendiri bermacam-macam, antara lain kelainan pembuluh koroner, infark miokard, miokarditis, kardiomiopati, kelainan katup jantung, dan akibat kelainan genetik. ${ }^{1,4}$ Penyakit pembuluh darah koroner merupakan penyebab kematian terbanyak. Di Indonesia seperti yang dilaporkan oleh badan Litbang Departemen Kesehatan RI presentase kematian akibat penyakit ini meningkat dari 5,9\% (1975) menjadi 9,1\% (1981), 16,0\% (1986) dan 19,0\% (1995). ${ }^{5}$

Di Indonesia masih sukar didapat insiden kematian mendadak yang sebenarnya. ${ }^{5}$ Di Manado sendiri belum ada data yang menjelaskan insiden kematian mendadak, khususnya kematian mendadak yang disebabkan oleh penyakit jantung. Penelitian ini bertujuan untuk mengetahui bagaimana temuan otopsi pada kasus kematian mendadak akibat penyakit jantung di BLU RSU Prof. Dr. R.D. Kandou Manado periode 2007-2011.

\section{METODE PENELITIAN}

Jenis penelitian yang digunakan adalah deskriptif observasional, yaitu mengobservasi data yang telah ada dan mendeskripsikan hasil penelitian yang didapatkan. Data yang digunakan merupakan data sekunder yang diambil dari dokumentasi hasil otopsi di bagian Ilmu Kedokteran Forensik BLU RSU Prof. Dr. R.D. Kandou Manado periode 2007-2011 dengan variabel bebas kematian mendadak akibat penyakit jantung dan variabel terikatnya temuan otopsi pada kematian mendadak akibat penyakit jantung.

\section{HASIL DAN PEMBAHASAN}

Selama periode 2007 sampai dengan 2011, total jumlah kasus forensik yang masuk di bagian ilmu kedokteran Forensik BLU RSU Prof. dr. R.D. Kandou Manado berjumlah total 873 kasus dengan deskripsi 159 kasus pada tahun 2007, 170 kasus pada tahun 2008, 194 kasus pada tahun 2009, 161 kasus pada tahun 2010, dan 189 kasus pada tahun 2011. Dari sejumlah kasus tersebut, diantaranya terdapat 62 kasus penemuan mayat dengan deskripsi 4 kasus pada tahun 2007, 6 kasus pada tahun 2008, 8 kasus pada tahun 2009, 27 kasus pada tahun 2010 dan 17 kasus pada tahun 2011. Sejumlah kasus penemuan mayat ini kemudian dibuktikan dengan otopsi sehingga didapatkan hasil total 10 mayat yang telah terbukti merupakan kasus kematian mendadak akibat penyakit jantung sedangkan 52 kasus lainnya terbukti disebabkan oleh sebab lain seperti pembunuhan, kecelakaan lalu lintas, tenggelam, dan bunuh diri.

Pada 62 kasus penemuan mayat tersebut, 20 diantaranya telah dilakukan otopsi dan sebab kematian telah ditentukan dengan pasti. 42 kasus lainnya dijadikan sebagai dugaan kasus kematian mendadak. Hal ini disebabkan karena tidak lengkapnya data yang didapatkan dari bagian dokumentasi dan administrasi Ilmu Kedokteran Forensik BLU RSU Prof. Dr. R.D. Kandou Manado. Surat permintaan pemeriksaan yang datang dari kepolisian seharusnya dilengkapi pula dengan hasil pemeriksaan berupa Visum et Repertum dari permintaan kasus tersebut. Namun pada kenyataanya, banyak ditemukan surat permintaan dari kepolisian saja tanpa disertai dengan hasil pemeriksaannya. Hal ini menjadi salah satu kendala bagi peneliti untuk mendapatkan data yang lengkap, sehingga data-data yang 
Rorora, Tomuka, Siwu; Temuan Otopsi pada Kematian Mendadak...

Tabel 1. Jumlah kasus forensik yang masuk di bagian Ilmu Kedokteran Forensik BLU RSU Prof. dr. R.D. Kandou Manado periode 2007-2011.

\begin{tabular}{|l|l|l|l|l|l|l|l|}
\hline No. & Thn & $\begin{array}{l}\text { Jumlah } \\
\text { Kasus } \\
\text { yang } \\
\text { masuk }\end{array}$ & $\begin{array}{l}\text { Kasus } \\
\text { Penemuan } \\
\text { Mayat }\end{array}$ & $\begin{array}{l}\text { Yang } \\
\text { Dilakukan } \\
\text { Otopsi }\end{array}$ & $\begin{array}{l}\text { Dugaan } \\
\text { Kematian } \\
\text { Mendadak }\end{array}$ & $\begin{array}{l}\text { Terbukti } \\
\text { Akibat } \\
\text { penyakit } \\
\text { jantung }\end{array}$ & $\begin{array}{l}\text { Terbukti } \\
\text { Sebab } \\
\text { Lain }\end{array}$ \\
\hline 1. & 2007 & 159 & 4 & 2 & 2 & 2 & - \\
\hline 2. & 2008 & 170 & 6 & 2 & 4 & 2 & - \\
\hline 3. & 2009 & 194 & 8 & 2 & 6 & 2 & - \\
\hline 4. & 2010 & 161 & 27 & 8 & 19 & 2 & 6 \\
\hline 5. & 2011 & 189 & 17 & 6 & 11 & 2 & 4 \\
\hline \multicolumn{2}{l}{ Total } & 873 & 62 & 20 & 42 & 10 & 10 \\
\hline
\end{tabular}

Tabel 2. Jumlah Data Kematian Mendadak yang Dibuktikan dengan Pemeriksaan Mikroskopik

\begin{tabular}{|l|l|l|}
\hline No. & Jumlah Kematian Mendadak akibat Penyakit Jantung \\
\hline 1. & Dilakukan pemeriksaan mikroskopik & 5 \\
\hline 2. & Tidak dilakukan pemeriksaan mikroskopik & 5 \\
\hline Total & 10 \\
\hline
\end{tabular}

Tabel 3. Uraian Hasil Otopsi Pada Kematian Mendadak Akibat Penyakit Jantung di bagian Ilmu Kedokteran Forensik BLU RSU Prof. dr. R.D. Kandou Manado periode 2007-2011.

\begin{tabular}{|c|c|c|}
\hline Tahun & No. & Uraian Hasil Otopsi \\
\hline \multirow[t]{2}{*}{2007} & 1. & $\begin{array}{l}\text { Pembesaran jantung dan penyumbatan pembuluh darah sebesar } 50 \% \\
\text { serta terdapat jaringan lemak matur diantara serabut otot jantung. }\end{array}$ \\
\hline & 2. & $\begin{array}{l}\text { Serangan jantung dengan pembesaran jantung dan pengerasan } \\
\text { pembuluh nadi serta bercak berwarna pucat yang dikelilingi bercak } \\
\text { warna kemerahan. }\end{array}$ \\
\hline \multirow[t]{2}{*}{2008} & 3. & 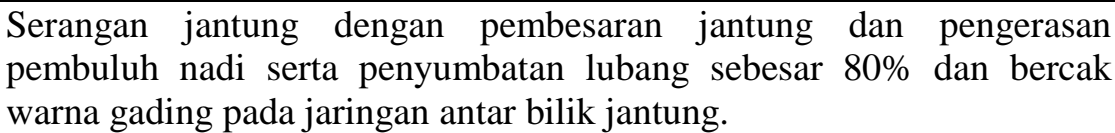 \\
\hline & 4. & Pembesaran jantung dan penyumbatan arteri koroner. \\
\hline \multirow[t]{2}{*}{2009} & 5. & $\begin{array}{l}\text { Kegagalan otot jantung dengan pembesaran jantung dan penyumbatan } \\
\text { pembuluh nadi sebesar } 90 \% \text { pada dinding bilik kanan dan kiri terdapat } \\
\text { bercak warna gading dan pada jaringan antar bilik bagian ujung } \\
\text { terdapat bercak warna gading disekitarnya warna kemerahan serta } \\
\text { terdapat pula pengerasan pada pembuluh darah. }\end{array}$ \\
\hline & 6. & $\begin{array}{l}\text { Perkapuran pembuluh darah dengan penyumbatan pembuluh nadi } \\
\text { sebesar }<40 \% \text { terdapat pula pengerasan pembuluh darah yang tidak } \\
\text { merata. }\end{array}$ \\
\hline \multirow[t]{2}{*}{2010} & 7. & $\begin{array}{l}\text { Kematian otot jantung dengan pembesaran jantung dan penyumbatan } \\
\text { pembuluh nadi sebesar } 80 \% \text { pada dinding depan jantung terdapat } \\
\text { bercak warna putih gading. }\end{array}$ \\
\hline & 8. & $\begin{array}{l}\text { Perkapuran pada pembuluh darah jantung dan terdapat jaringan } \\
\text { berwarna merah kelabu. }\end{array}$ \\
\hline \multirow[t]{2}{*}{2011} & 9. & $\begin{array}{l}\text { Pembesaran jantung dengan penebalan dan penyumbatan arteri koroner } \\
\text { sebesar } 50 \% \text {. }\end{array}$ \\
\hline & 10. & nyumbatan arteri koroner. \\
\hline
\end{tabular}


Tabel 4. Karakteristik Penyakit Jantung yang Menyebabkan Kematian Mendadak di bagian Ilmu Kedokteran Forensik BLU RSU Prof. dr. R.D. Kandou Manado periode 2007-2011.

\begin{tabular}{|c|c|c|c|c|c|}
\hline \multirow[b]{2}{*}{ No. } & \multirow[b]{2}{*}{ Tahun } & \multicolumn{4}{|c|}{ Jenis Penyakit Jantung } \\
\hline & & $\begin{array}{l}\text { Penyakit } \\
\text { Arteri } \\
\text { Koroner }\end{array}$ & $\begin{array}{l}\text { Lesi Miokard, Katup } \\
\text { Jantung, } \\
\text { Perikardium, } \\
\text { Endokardium }\end{array}$ & $\begin{array}{l}\text { Lesi } \\
\text { Aorta }\end{array}$ & $\begin{array}{l}\text { Penyakit } \\
\text { Jantung } \\
\text { Kongenital }\end{array}$ \\
\hline 1. & 2007 & - & 2 & - & - \\
\hline 2. & 2008 & 1 & 1 & - & - \\
\hline 3. & 2009 & 1 & - & 1 & - \\
\hline 4. & 2010 & 2 & - & - & - \\
\hline 5. & 2011 & 1 & 1 & - & - \\
\hline
\end{tabular}

tidak lengkap tersebut hanya dapat dijadikan sebagai dugaan kasus kematian mendadak

Kendala lain yang ditemukan pada saat melakukan penelitian ini adalah adanya kasus yang seharusnya dilakukan otopsi namun tidak dilakukan karena keluarga yang bersangkutan menolak. Dalam isi surat tersebut dikatakan bahwa keluarga yang bersangkutan percaya bahwa kematian anggota keluarganya tersebut merupakan suatu kematian wajar yang disebabkan oleh penyakit yang sebelumnya telah diderita si korban sehingga tidak menghendaki dilakukannya pemeriksaan lebih lanjut. Hal ini kemungkinan disebabkan oleh pengetahuan masyarakat yang masih kurang tentang otopsi dan juga budaya dan anggapan masyarakat yang masih negatif pada pemeriksaan bedah mayat atau otopsi tersebut. Surat-surat penolakan otopsi inipun tidak semuanya masuk sebagai dokumentasi di bagian Ilmu Kedokteran Forensik BLU RSU Prof. Dr. R.D. Kandou Manado sehingga kembali lagi menjadi suatu masalah ketidaklengkapan data. Faktor lainnya yang mungkin juga berpengaruh pada penolakan otopsi forensik ini antara lain agama dan sosial ekonomi. ${ }^{6,7}$

Hasil otopsi tidak hanya menunjukkan satu kelainan jantung yang pada akhirnya menyebabkan kematian mendadak. Pada kenyataannya, keadaan yang didapat dalam hasil penelitian ini adalah terdapat lebih dari satu kelainan jantung pada beberapa korban. Hal ini dapat disebabkan oleh penyakit penyerta lain yang diderita oleh korban, sebagai contoh: adanya riwayat hipertensi karena sebab kematian tidak diketahui dengan pasti.

pada penderita sehingga terjadi penebalan miokardium. $^{8}$

Penentuan diagnosis penyakit lesi miokard diambil berdasarkan hasil otopsi yang didapatkan, yaitu adanya pembesaran jantung lebih dari ukuran normal (kira-kira sebesar kepalan tangan korban), berat jantung yang lebih dari 600 gram, penebalan massif dinding otot jantung, serta ditemukannya hipertrofi sel otot dan infiltrasi sel lemak matur yang dibuktikan pada pemeriksaan mikroskopik bagian patologi anatomi telah cukup memberikan dasar untuk penegakan diagnosis lesi miokard sebagai penyebab utama kematian mendadak pada korban, sehingga pada tabel 3 didapatkan 4 kematian mendadak akibat lesi miokard. Selain 2 jenis penyakit jantung yang telah disebutkan sebelumnya, ditemukan pula 1 kematian mendadak akibat lesi pada aorta. Diagnosis ini diambil berdasarkan kesimpulan hasil otopsi yang menyebutkan bahwa penyebab kematian korban adalah akibat aneurisma aorta.

Jenis kelamin juga berpengaruh pada insiden kematian mendadak akibat penyakit jantung. Data yang didapatkan dari hasil penelitian Bagian Ilmu Kedokteran Forensik FKUI pada tahun 1990 menunjukkan dari 2461 kasus yang dilaporkan, kematian mendadak pada laki-laki berjumlah 227 kasus dan perempuan berjumlah 50 kasus. Sedangkan pada tahun 1991 dari 2557 kasus yang dilaporkan, didapatkan 228 pada lakilaki dan 54 pada perempuan. ${ }^{5}$ Hal ini sejalan 
Rorora, Tomuka, Siwu; Temuan Otopsi pada Kematian Mendadak...

dengan hasil penelitian yang didapatkan, bahwa 9 dari 10 korban kematian mendadak akibat penyakit jantung adalah laki-laki.

Tabel 5. Kematian Mendadak Akibat Penyakit Jantung Berdasarkan Jenis Kelamin.

\begin{tabular}{|l|c|}
\hline Jenis Kelamin & Jumlah \\
\hline Laki - laki & 9 \\
\hline Perempuan & 1 \\
\hline
\end{tabular}

Hal lain yang juga perlu diperhatikan pada kematian mendadak akibat penyakit jantung adalah usia. Pada penelitian ini tidak didapatkan kematian mendadak akibat penyakit jantung kongenital, karena tidak didapatkan korban dengan usia anak-anak sampai dewasa muda. Semua sampel pada penelitian ini berumur diatas 40 tahun, sehingga tidak memenuhi kriteria penyakit jantung kongenital. Hal ini sesuai dengan hasil penelitian yang dilakukan di RS Sukanto Jakarta periode 2006-2010 yang mendapatkan hasil adanya hubungan yang signifikan antara insiden kematian mendadak dan usia. Dikatakan bahwa kematian mendadak pada bayi dan anak-anak lebih sering disebabkan oleh penyakit non-jantung, sedangkan pada usia dewasa lebih dominan terjadi akibat penyakit jantung. ${ }^{9}$ Hasil otopsi yang 5 diantaranya telah dibuktikan dengan pemeriksaan mikroskopik dari bagian patologi anatomi juga cukup jelas membuktikan bahwa sebagian besar kasus merupakan kematian mendadak akibat penyakit jantung kronik atau menahun.

\section{PENUTUP}

Dari hasil penelitian ini maka dapat disimpulkan bahwa penyebab terbanyak kematian mendadak akibat penyakit jantung di BLU RSU Prof. Dr. R.D. Kandou Manado berdasarkan hasil otopsi adalah penyakit arteri koroner. Penyumbatan lumen pada penyakit arteri koroner ini paling banyak lebih dari $80 \%$. Penyakit jantung lainnya yang menjadi penyebab terbanyak setelah penyakit jantung koroner adalah akibat lesi miokard. Bagi bagian dokumentasi dan administrasi di bagian Ilmu Kedokteran Forensik diharapkan untuk dapat lebih teliti lagi dalam penyimpanan berkasberkas kasus yang masuk. Perlu dilakukan penelitian lebih lanjut dengan data yang lebih banyak dan lebih jelas sehingga dapat lebih jelas menggambarkan penyakit jantung penyebab kematian terbanyak di bagian Ilmu Forensik BLU RSU Prof. Dr. R.D. Kandou Manado.

\section{DAFTAR PUSTAKA}

1. Kristanto E, Tjahjanegara W. Kematian Mendadak. Cited 2012 sep 25. Available from:

http://www.scribd.com/doc/36945361/KE MATIAN-MENDADAK.

2. Schoppe $\mathrm{CH}$, Lantz PE, Denton JS. Pathology of Sudden Natural Death. Cited 2012 sep 30. Available from : http://emedicine.medscape.com/article/16 80282-overview.

3. WHO. The Top 10 Causes of Death. Cited 2012 sep 30. Available from: http://www.who.int/mediacentre/factsheet s/fs310/en/index.html.

4. Sovari AA, Kocheril AG, Baas AS. Sudden Cardiac Death. Cited 2012 oct 15. Available from: http://emedicine.medscape.com/article/15 1907-overview.

5. Anonim. Sudden Death Fix. Cited 2012 sep 25. Available from: http://www.scribd.com/doc/59508791/Sud den-Death-Fix.

6. Mikail B. 16 Mei 2012. Anggapan Keliru Tentang Otopsi di Masyarakat. Kompas, Jakarta.

7. Afandi, D. Otopsi Virtual. Majalah Kedokteran Indonesia 59. 2009.

8. Anwar BT. Faktor Risiko Penyakit Jantung Koroner. 2004

9. Isselbacher KJ, Braunwald E, Wilson JD, Martin JB, Fauci AS, Kasper DL. Harrison Prinsip-prinsip ilmu penyakit dalam. 1999. EGC. 